\title{
MATHEMATICAL ISSUES IN TWO-DIMENSIONAL ARITHMETIC FOR ANALYZE STUDENTS' METACOGNITION AND CREATIVE THINKING SKILLS
}

\author{
Mohammad Tohir ${ }^{*}$ iD , Muhasshanah Muhasshanah² \\ 1,2Universitas Ibrahimy, Situbondo, Indonesia \\ ${ }^{1 *}$ matematohir@ibrahimy.ac.id, 22muhasshanah@ibrahimy.ac.id
}

\begin{tabular}{lll}
\hline Received: November 16, 2021 & Revised: December 27, 2021 & Accepted: December 31, 2021 \\
\hline
\end{tabular}

\begin{abstract}
:
This study aimed to analyze the level of students' metacognition skills and creative thinking in the generalization of a two-dimensional arithmetic sequence. A qualitative descriptive is a scientific approach used in this study. Students' of the Mathematics Education Study Program in Tarbiyah Faculty of Ibrahimy University are subjects in the study. Through this article, the author will describe the results of the research in the combinatorics course. The initial data was collected by assigning open problem-solving assignments to students and conducting documentation studies on students in generating arithmetic generalization patterns based on function formulae. Then, students are assigned to complete the second task, which is to compile a two-dimensional arithmetic sequence based on the multilevel function formula of arranged arithmetic. The analysis model of Miles and Huberman is the analytical methodology used in this study. The collected data indicated that the level of students' creative thinking skills in combinatorics could be in the category of creative enough $(16.67 \%)$, creative (50\%), and very creative (33.33\%). While the other analyzed data showed that the student's level of metacognitive on level $3(77.78 \%)$ and the remainder on level $4(22.22 \%)$. These analysis results are influenced by several factors such as accuracy in compiling numbers and expanding data, conceptual mastery of arithmetic progression permutation concept, and its application, the tendency of students' to rely on memorization and imitation of the examples.
\end{abstract}

Keywords: Mathematical Issues, Two-Dimensional Arithmetic, Metacognition, Creative Thinking Skills

How to Cite: Tohir, M., \& Muhasshanah, M. (2021). Mathematical Issues in Two-Dimensional Arithmetic for Analyze Students' Metacognition and Creative Thinking Skills. Alifmatika: Jurnal $\begin{array}{llll}\text { Pendidikan dan Pembelajaran } & \text { Matematika, 3(2), } & \text { 170-183. }\end{array}$ https://doi.org/10.35316/alifmatika.2021.v3i2.170-183

\section{INTRODUCTION}

Each student at Ibrahimy University has been selected for screening of new students'. They should have been the basic knowledge to continue the learning process at a higher stage, including students majoring in Mathematics Education. The students have provided some material math in high school. The Mastery level of mathematics for students is still unknown specifically for each course. But, according to the document test scores that were collected during the matriculation, nearly $75 \%$ of students' got a low value for the course Calculus and

Content from this work may be used under the terms of the Creative Commons AttributionShareAlike 4.0 International License that allows others to share the work with an acknowledgment of the work's authorship and initial publication in this journal. 
Analysis and Logic and Evidence. They should be better prepared to undergo study and get good grades for these basic materials. Besides, mathematics education students' will be served as a mathematics teachers. They will teach students about calculus, analysis, logic, and other mathematics materials. So the level of students in mastering materials should be at the level of the application, because these courses form the basis of other Courses, one of which is the Combinatorics Course. Through Combinatorial Courses, students are expected to be able to think analytically, systematically, logically, critically, creatively, and innovatively. Combinatorial courses are considered challenging to learn since they demand rational thinking, creative talents, and a reasonably high level of metacognition.

Munandar (2012) defines creative thinking as a person's capacity to reflect fluency, flexibility, originality, and elaboration features. The steps of creative thinking, according to Siswono (Mohammad Tohir, Abidin, Dafik, \& Hobri, 2018), involve synthesizing ideas, building ideas, planning the implementation of ideas, and employing these ideas to produce something or new goods. Creativity is the new product in question. In this scenario, thinking about what to think is connected to one's knowledge of one's capacity to sharpen and improve in addressing a certain problem, and is referred to as metacognition.

Metacognition has the potential to play an active and significant role in regulating and managing a person's cognitive processes in learning and thinking. According to Gartmann \& Freiberg, (1995), that in the process of solving problems a person realizes and organizes his thoughts about what to do in solving problems, chooses the right strategy to use in finding solutions, and questions himself about the problem. Metacognition abilities influence pupils' intellect as well as the development of their creative thinking processes (Barak, 2010; Preiss, Cosmelli, Grau, \& Ortiz, 2016; Hargrove, 2013; Romli, 2012).

The results of research conducted by Kholid \& Lestari (2019) showed that students with high math abilities have the best metacognition. The results of research conducted by Tohir (2019) showed that several factors affect the level of students' metacognition and creative thinking skills, namely understanding of information, skills in choosing strategies, developing the right strategy, elaborating answers, mastery of mathematical material, and the tendency to rely on memorization. Meanwhile, students with moderate and low mathematical abilities only fulfill below level 5 the sub-indicator of metacognition knowledge and below level 3 the sub-indicator of metacognition skills (Muttaqin, Susanto, Hobri, \& Tohir, 2021). Meantime, the results of research conducted by Sari, Ikhsan, \& Saminan (2017) showed that there are significant differences between high, medium, and low group students in the creative thinking process of students in solving math problems based on the Wallas model. The results of research conducted by Rahmawati (2016) showed that through Quipper School-assisted SSCS learning, students' creative thinking abilities are influenced by their metacognitive awareness.

Based on the description above, it is necessary to conduct follow-up research on students' metacognition skills and students' creative thinking skills in combinatorial subjects. By knowing student mastery, will become a reference in implementing improvements in the implementation of learning to increase the level of student mastery, especially combinatorial subjects.

Alifmatika: Jurnal Pendidikan dan Pembelajaran Matematika, December 2021, Vol. 3, No. 2 


\section{RESEARCH METHODS}

In this study, qualitative research was employed as a research approach. The following features characterize qualitative research: the context as a whole, people as a tool or instrument, the use of qualitative methodologies, inductive data analysis, data-based theory creation, descriptive data, and being more concerned with the process than the process. The emphasis determines the bounds of the results, there are unique requirements for data validity, the design is provisional, and the study findings are the outcome of a collective choice (Suntusia, Dafik, \& Hobri, 2021; Tohir et al., 2020; Munawwarah et al., 2020; Tohir et al., 2018). The participants in this study were 18 students from Ibrahimy University's Mathematics Tadris Study Program, Tarbiyah Faculty. Students are expected to offer a full picture of their metacognition abilities as well as the caliber of their creative thinking abilities.

The data collecting strategy is the most crucial phase in this study since it is responsible for obtaining accurate data to be examined on the subject at hand. The assignment was presented in order to obtain data on students' metacognition skills and creative thinking abilities in combinatorial areas. The collected data will be minimized, presented, summarized, and confirmed. Data verification was accomplished using triangulation, peer review, and persistent monitoring.

The data for the analysis came from student assignments. Students are given the job to assess their capacity to think critically. In terms of creative thinking categorization, it is divided into five groups based on indicators of creative thinking level: extremely creative, creative, somewhat creative, less creative, and not creative. According to Siswono (Tohir et al., 2021; Abidin \& Tohir, 2019; Tohir, Susanto, Hobri, Suharto, \& Dafik, 2018), the level division is effective in predicting students' creative thinking ability, particularly in mathematics. While the following data analysis is gathered from the level of awareness in the cognitive process. According to Swartz and Perkins (Sophianingtyas \& Sugiarto, 2013), it consists of (1) tacit usage, (2) conscious use, (3) strategic use, and (4) reflective use.

Data from qualitative research can be shown in the form of brief explanations, charts, category correlations, flowcharts, and other visual aids (Tohir, 2017). Sugiyono quotes Miles and Huberman as saying (Munawwarah et al., 2020), narrative text was the most often utilized type of data display in the past for qualitative data study. In qualitative research, narrative writing is the most commonly utilized data presentation format. Data presentation includes categorizing and identifying data, as well as producing data sets that are arranged and classified in order to reach a conclusion. The findings will be useful in undertaking more studies.

\section{RESEARCH RESULT}

Data collection begins with understanding the basic formulas of arithmetic sequences and arithmetic series, namely arithmetic sequences and arithmetic series. An arithmetic sequence is a sequence whose terms are obtained by adding a fixed number to the preceding term. Fixed numbers are called differences or differences and are denoted by the letter " $b$ ", the first syllable $\left(U_{1}\right)$ is denoted by

Alifmatika: Jurnal Pendidikan dan Pembelajaran Matematika, December 2021, Vol. 3, No. 2 
the letter " $a$ ", and the formula for the nth syllable of the arithmetic sequence is $U_{n}=$ $a+(n-1) b$. Meanwhile, arithmetic series is also called arithmetic series. When the terms in the arithmetic sequence are added together, the arithmetic sequence is obtained. Thus, the standard form of an arithmetic sequence is $a+(a+b)+(a+$ $2 b)+(a+3 b)+\ldots+(a+(n-1) b)$. If the number of $n$ terms of the arithmetic sequence is given by $S_{n}$, then the formula is $S_{n}=\frac{n}{2}\left(a+U_{n}\right)$. After that, the pattern discovery process is carried out by making a table in advance as follows.

\section{The Patterned Line Fill Format}

Students must seek the arithmetic sequence formula when generalizing. It can be made up of one or more formulae that follow a sequence pattern. For example, if the sequence pattern has two types of formulae, the formula that must be expressed is as follows:

\begin{tabular}{|c|c|c|c|c|c|c|}
\hline$i$ & 1 & 2 & 3 & 4 & 5 & 6 \\
\hline$f\left(x_{i}\right)$ & 4 & 1 & 5 & 2 & 6 & 3 \\
\hline
\end{tabular}

$$
\Rightarrow \quad f\left(x_{i}\right)= \begin{cases}\frac{i+n+2}{2} & , \text { iodd } \\ \frac{i}{2} & , \text { ieven }\end{cases}
$$

\section{The Patterned Two-Dimensional Arithmetic Sequence}

In the next step, In the following function formula, it is called $P_{m, d}^{n}(i, j)$, which denotes a partition I $\mathrm{j}$ ) with a certain number of $n$ and $m$, and has a difference in the sequence. In the 2-dimensional table, I depend on the number of $n$, just as it does in the 1-dimensional table, but $j$ depends on the number of $m$ that has been established. The pupils' next attempt is to fill in the table with numbers in order to discover the sequence pattern. Then add up the numbers in each column, and the sum of the numbers in each column must eventually form an arithmetic sequence.

\begin{tabular}{|c|c|}
\hline $\begin{array}{l}\text { General Formula Functions } \\
P_{m, 2 m}^{n}= \begin{cases}n(j-1)+2 i-1 & , j \text { odd } \\
n(j-2)+2 i & , j \text { odd }\end{cases} \end{array}$ & $\begin{array}{l}\text { General Formula Functions } \\
P_{m, \frac{1}{2} m}^{n}= \begin{cases}n(j-1)+\frac{i+1}{2} & , j \text { and i odd } \\
n(j-1)+\frac{i}{2} & , j \text { and i even } \\
\frac{1}{2}[n(2 j-1)+i+1] & , j \text { odd dani even } \\
\frac{1}{2}[n(2 j-1)+i] & , j \text { evenand ieven }\end{cases} \end{array}$ \\
\hline
\end{tabular}

\section{Finding the Weight Function Formulas}

The next, generalize the arithmetic sequence pattern, namely $\sum_{j=1}^{m} P_{m, d}^{n}(i, j)$. where $\sum_{j=1}^{m} P_{m, d}^{n}(i, j)$ is the sum of the terms from each column starting from $j=1$ to $j=$ $m$. Look at the following step for generalizing formula of $\sum_{j=1}^{m} P_{m, d}^{n}(i, j)$ for more details:

Alifmatika: Jurnal Pendidikan dan Pembelajaran Matematika, December 2021, Vol. 3, No. 2 


$$
\begin{aligned}
\sum_{j=1}^{m} P_{m, d}^{n}(i, j) & =\sum_{j=1}^{m}(j-1) n+i=\sum_{j=1}^{m} j n-n+i=\sum_{j=1}^{m} j n+\sum_{j=1}^{m}(-n+i) \\
& =(1+2+3+\ldots+m) n+(-n+\mathrm{i}) m=\frac{m}{2}(1+m) n-m n+m i \\
& =\frac{m n}{2}(m-1)+m i
\end{aligned}
$$

\section{DISCUSSION}

In this discussion section, the author will present the results of the analysis of the level of metacognition skills and students' creative thinking abilities based on high, medium, and low mathematical abilities in compiling data and looking for formulas based on these data. The following is a description of the student's work.

\section{Findings on One-Dimensional Arithmetic Sequences}

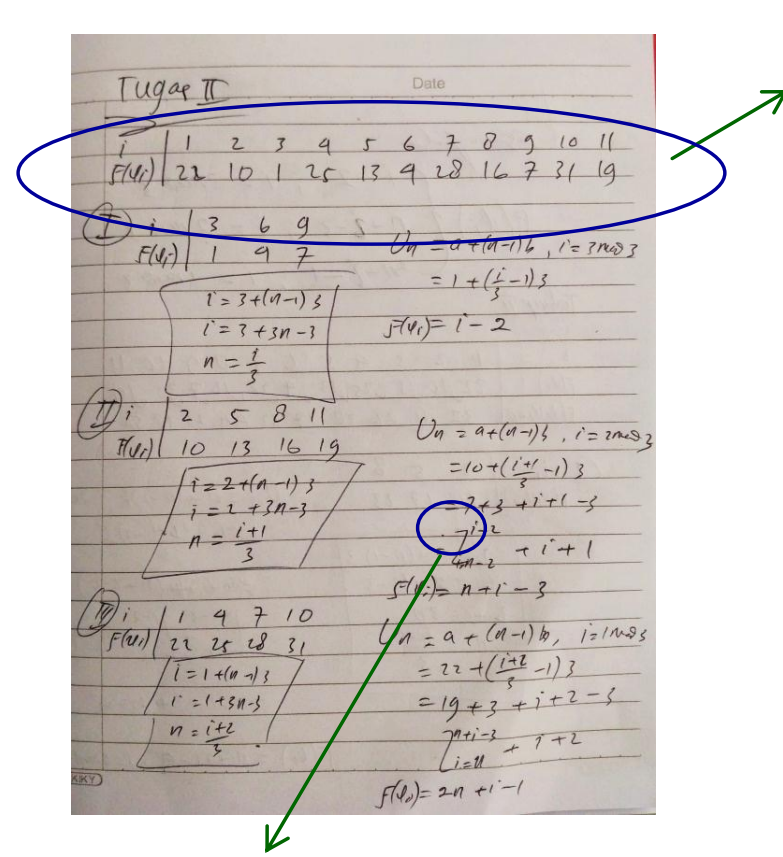

Because the number 1 is already in the 3-term, this assembled data is more creative.

Because 10 is a parameter, the numbers 7 and 3 are chosen, with 7 being the nth phrase formula for $I=3 \bmod 3$.
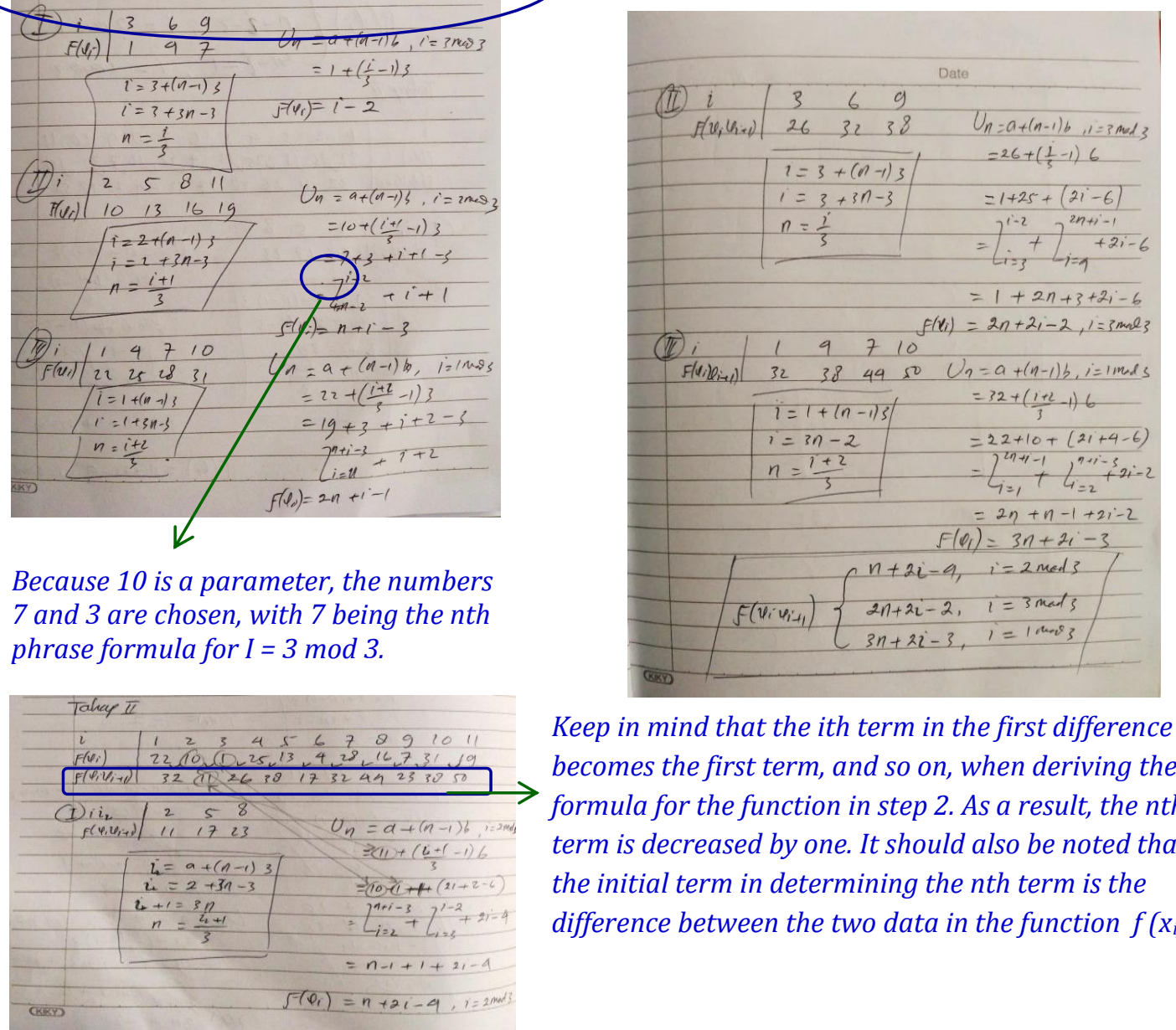

Keep in mind that the ith term in the first difference becomes the first term, and so on, when deriving the formula for the function in step 2. As a result, the nth term is decreased by one. It should also be noted that the initial term in determining the nth term is the difference between the two data in the function $f\left(x_{i}\right)$

Figure 1. Define a formula function level 2, ie $f\left(x_{i} x_{i+1}\right)$

Alifmatika: Jurnal Pendidikan dan Pembelajaran Matematika, December 2021, Vol. 3, No. 2 
Based on the above, the formulas of the function at level 2 or $f\left(x_{i} x_{i+1}\right)$ were created, but level 2 is still unfinished in determining the generalization formula for other functions with a constant difference. After the data expanded to the hundredth term, the constant difference can't be found. It can be concluded that data can't be determined by the found formula. At this point, just 61.11 percent of students are able to find a formula that works well.

There are a total of 32 exciting experiences of each student from the comments of the students' when generalizing formulas. Based on the data created by each student, not all data can be generalized by the current formula and it is used for generalizing function on the next level, such as the function $f\left(x_{i} x_{i+\mathrm{n}}\right)$. It is because of the limited ability of students' to think critically. As a result, the study switched to formula functions that are dependent on $i$ and $j$ or $P_{m, d}^{n}(i, j)$ formula, consider the following discussion.

\section{Findings on Two-Dimensional Arithmetic Sequences}

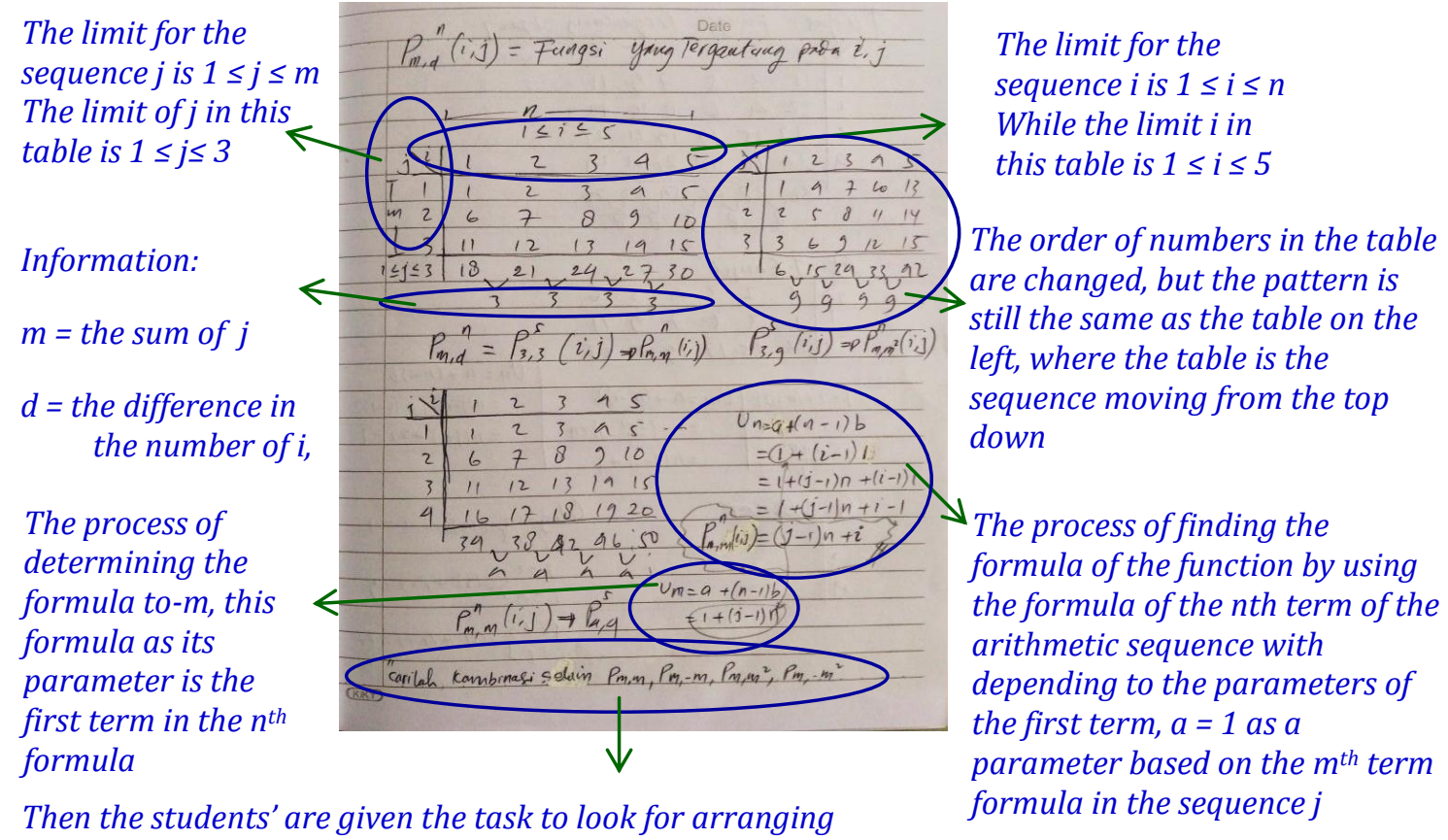

different numbers with the pattern discussed by the lecturer, that

is Find a combination other than $P_{m, m} ; P_{m,-m} ; P_{m, m^{2}} ; P_{m,-m^{2}}$

Figure 2. Define a formula function of $P_{m, d}^{n}(i, j)$

There are many students' data that has been compiled by the students' could not be generalized although the data were sorted, for example, as in Figure 3 below. 


\section{Mohammad Tohir \& Muhasshanah Muhasshanah}

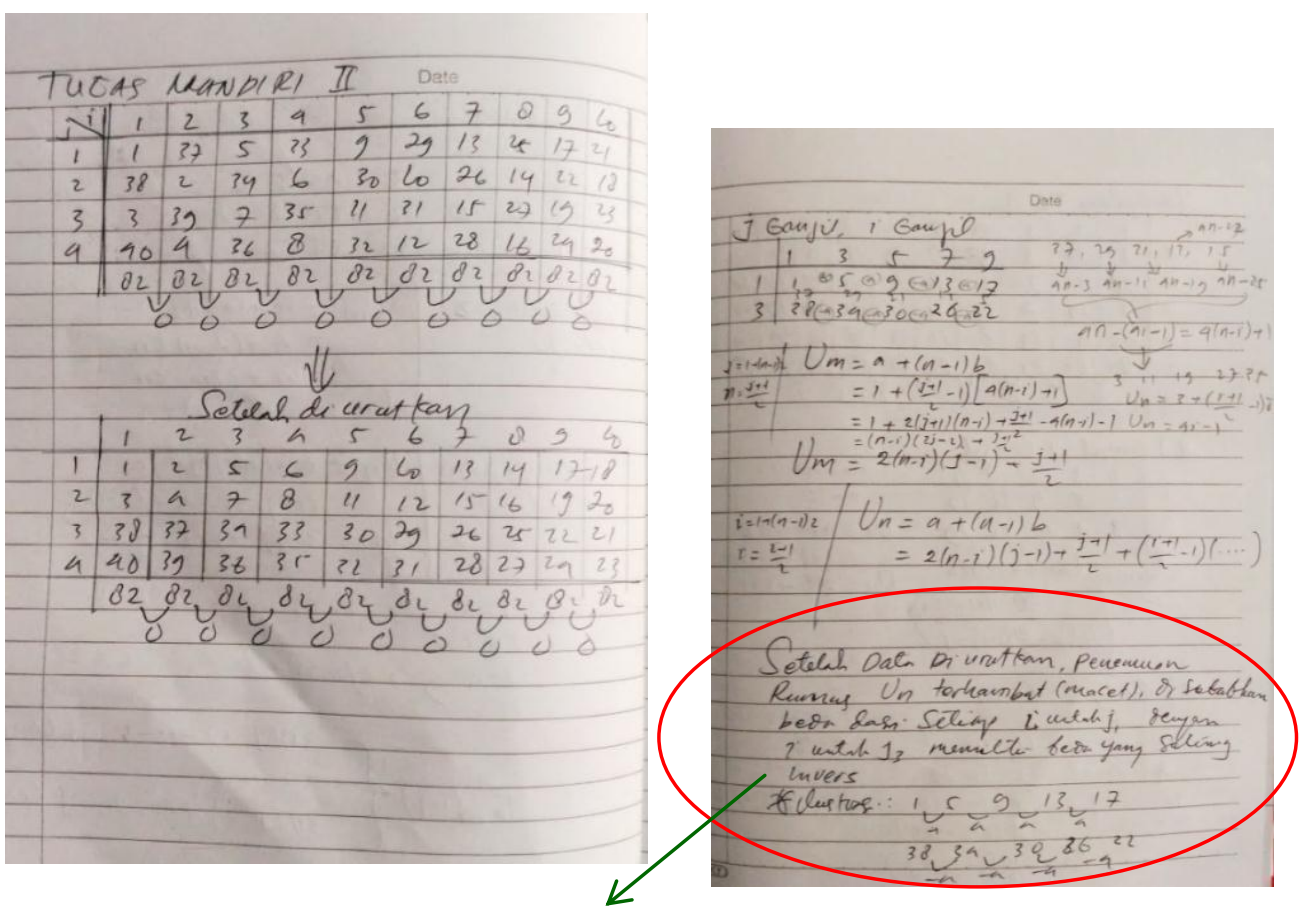

"Once the data is sorted, the invention of the formula $U_{n}$ obstructed (stalled), due to the difference of each $i$ and $j$, with each $i$ to $j_{3}$ have different are mutually inverse"

Figure 3. Determining formula functions $P_{m, d}^{n}(i, j)$ that fail

The data arrangement was not ordered, the formula was obtained properly. Consider the following picture.

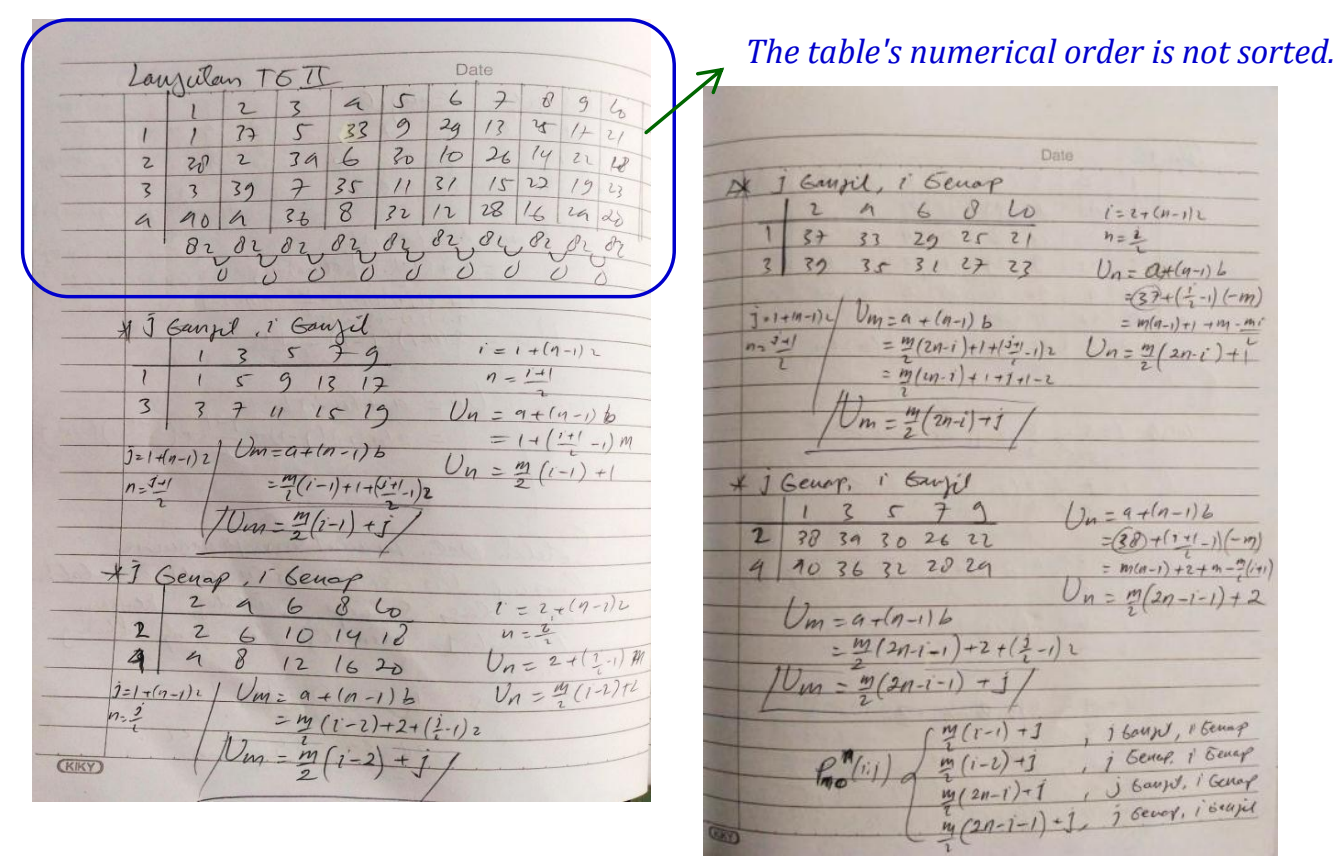

Figure 4. Define a formula function $P_{m, d}^{n}(i, j)$ with the arrangement of numbers is not sorted

Alifmatika: Jurnal Pendidikan dan Pembelajaran Matematika, December 2021, Vol. 3, No. 2 
Based on Figure 4, the generalization formula will require a four-stage process of finding the function formula, namely for the function formula in the $j$ and i sequence positions. The figures compiled in the data are categorized as very difficult so that the process of finding the function formula requires persistence and accuracy that is strong and patient.

\section{Findings on Weight Function Formulas}

The next step in this research carried out the process of the invention to the formula the amount of data that has been compiled by students', which is as follows.

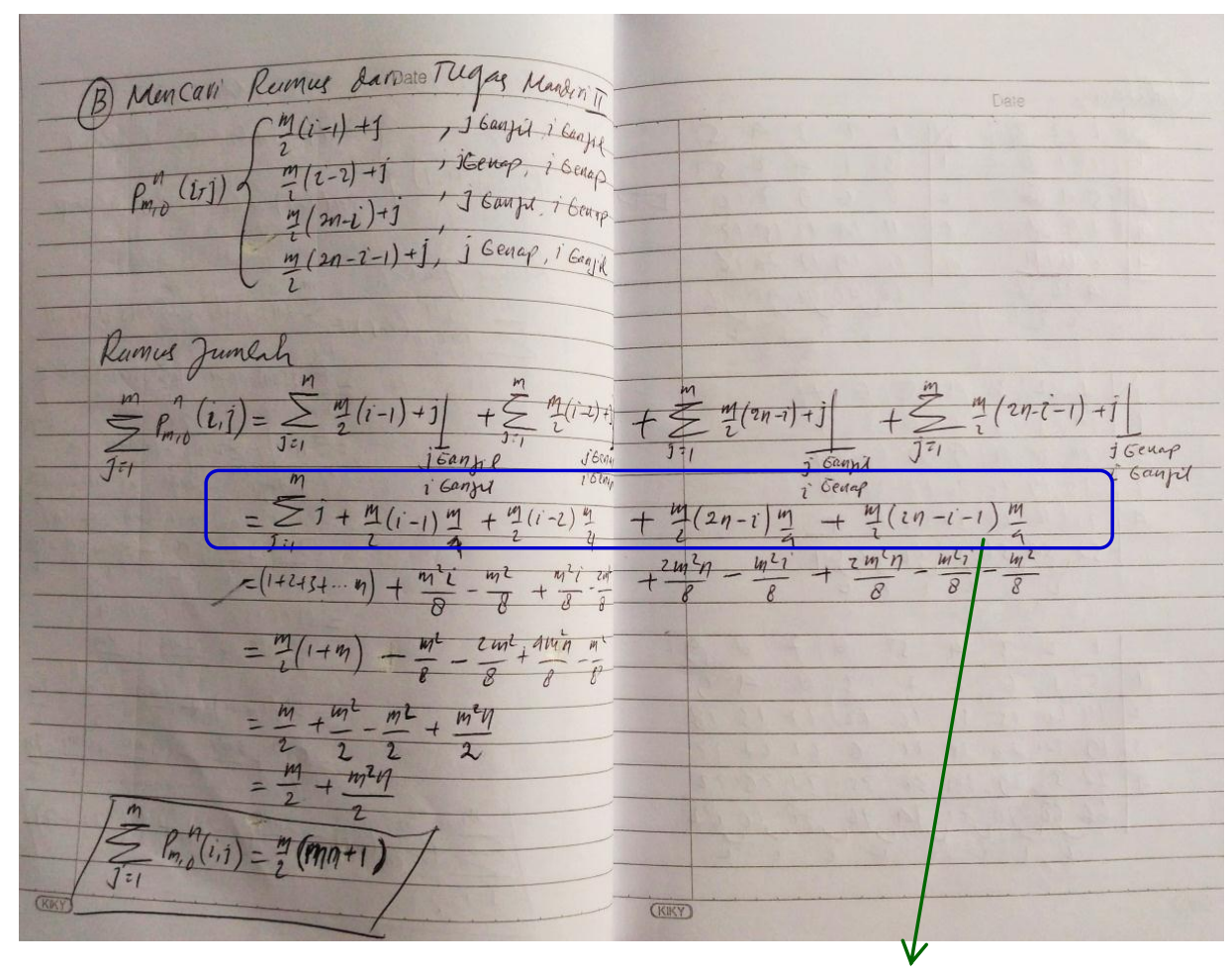

There are four compiled data, then each formula should be multiplied by a quarter for the obtained the valid formula.

Figure 5. Determining the amount formula of $\sum_{j=1}^{m} P_{m, d}^{n}(i, j)$

Based on the analysis in Figure 5, when determining the amount formula, it depends on the sum of formulas function obtained so that the amount formula at any rate multiplied by the inverse number of formulas function obtained. The process of determining the amount formula is difficult, because not all students' can find a formula for the sum easily. It needs the tenacity of its own self students'.

\section{RESULTS OF THE DATA ANALYSIS}

\section{Achievement of Test Result Based on Metacognition Level}

While the study's findings include the student metacognitive level, they are explained in Table 1 as follows. 
Table 1. Levels of Student Metacognition

\begin{tabular}{|c|c|c|}
\hline \multirow{2}{*}{ Level } & \multicolumn{2}{|c|}{ Student Metacognition Data } \\
\hline & Sum & Percentage (\%) \\
\hline Level 1 & 0 & 0 \\
\hline Level 2 & 0 & 0 \\
\hline Level 3 & 14 & 77,78 \\
\hline Level 4 & 4 & 22,22 \\
\hline
\end{tabular}

The data presented in Table 1 shows that the majority of students' at the level of 3. Level 3 is the kind of thinking that shows someone to organize his thoughts to realize specific strategies that improve the precision of thought. Most of the others are at level 4 , where level 4 is the type of thinking that shows one's reflection on his initiative to consider the cost and how to fix it.

The data achievement of metacognition level based on high, medium, and low group can be presented in Figure 6 below.

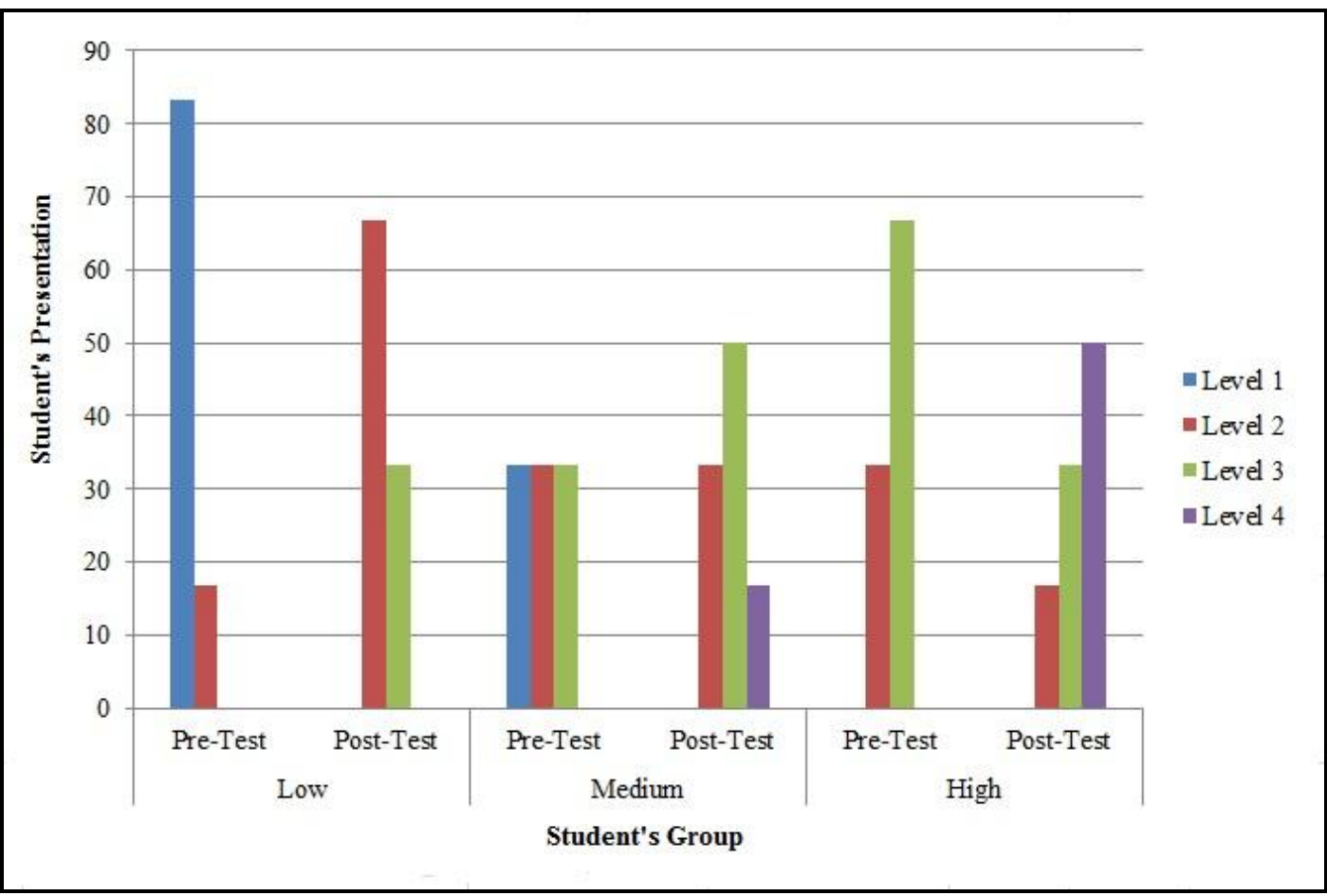

Figure 6. Data Achievement of Test Result Based on Metacognition Level

Based on the data of achievement of student metacognition level in Figure 6 above, it shows that the percentage of pre-test and the post-test result was increased significantly in the level obtained by the students. The low-level students obtained from the majority at level 1 become level 2. The enhancement for the group of students who obtained level 2 becomes level 3. And, for a high group of students who obtained the majority at level 3 become level 4 . The results of

Alifmatika: Jurnal Pendidikan dan Pembelajaran Matematika, December 2021, Vol. 3, No. 2 
improvement in each group of students were obtained, because the thinking process of students experiencing change caused by the treatment ranged from the process without thinking about the decision until the thought process that can show someone to reflect, consider, and revise the decision. It can be concluded that the thinking process of a person will increase significantly when they involve control over their cognitive processes. Thus, it shows that knowledge of cognition was a person's consciousness of what he really knows and cognitive regulation on how to manage cognitive activities effectively, so metacognitive is an awareness of self-knowledge by solving a problem creatively. This is consistent with Binkley et al. (2012) assertion that a person's creative thinking capacity has levels (levels) based on the works created in the relevant subject. Meanwhile, Tohir (2019) believes that creative thinking can be acquired and that this broad element of cognition may be increased by teaching and training. According to Sowden, Pringle, \& Gabora (2015), a person's creative thinking capacity may be increased by a knowledge of his creative thinking process and the many contributing elements, as well as through effective training. Meanwhile, according to the findings of Sitorus (2016), there is a need for a particular stage to educate students on how to uncover starting ideas when confronted with arithmetic solving issues and how to construct acceptable techniques based on the initial ideas gained.

\section{The Achievement of Students' Creative Thinking Skills Indicators}

Based on the researcher's findings, the level of creative thinking skills of students may be summarized in Table 2 below using precise indications.

Table 2. Creative Thinking Skills Levels

\begin{tabular}{|c|c|c|}
\hline \multirow{2}{*}{ Categories } & \multicolumn{2}{|c|}{$\begin{array}{l}\text { Data Level of Creative } \\
\text { Thinking Skills }\end{array}$} \\
\hline & Sum & Percentage (\%) \\
\hline $\begin{array}{c}\text { Level } 0 \\
\text { (not creative) }\end{array}$ & 0 & 0 \\
\hline $\begin{array}{c}\text { Level } 1 \\
\text { (Less creative) }\end{array}$ & 0 & 0 \\
\hline $\begin{array}{c}\text { Level } 2 \\
\text { (sufficient creative) }\end{array}$ & 3 & 16,67 \\
\hline $\begin{array}{l}\text { Level } 3 \\
\text { (creative) }\end{array}$ & 9 & 50,00 \\
\hline $\begin{array}{c}\text { Level } 4 \\
\text { (Very Creative) }\end{array}$ & 6 & 33,33 \\
\hline
\end{tabular}

According to the statistics in Table 2, pupils with creative thinking skills are included in the creative group, with as many as nine students. There are three times as many pupils who are sufficiently creative, while others are really creative. Data on the achievement of student creative thinking skills categorized on high, medium, and the low group can be presented into Figure 7 below:

Alifmatika: Jurnal Pendidikan dan Pembelajaran Matematika, December 2021, Vol. 3, No. 2 


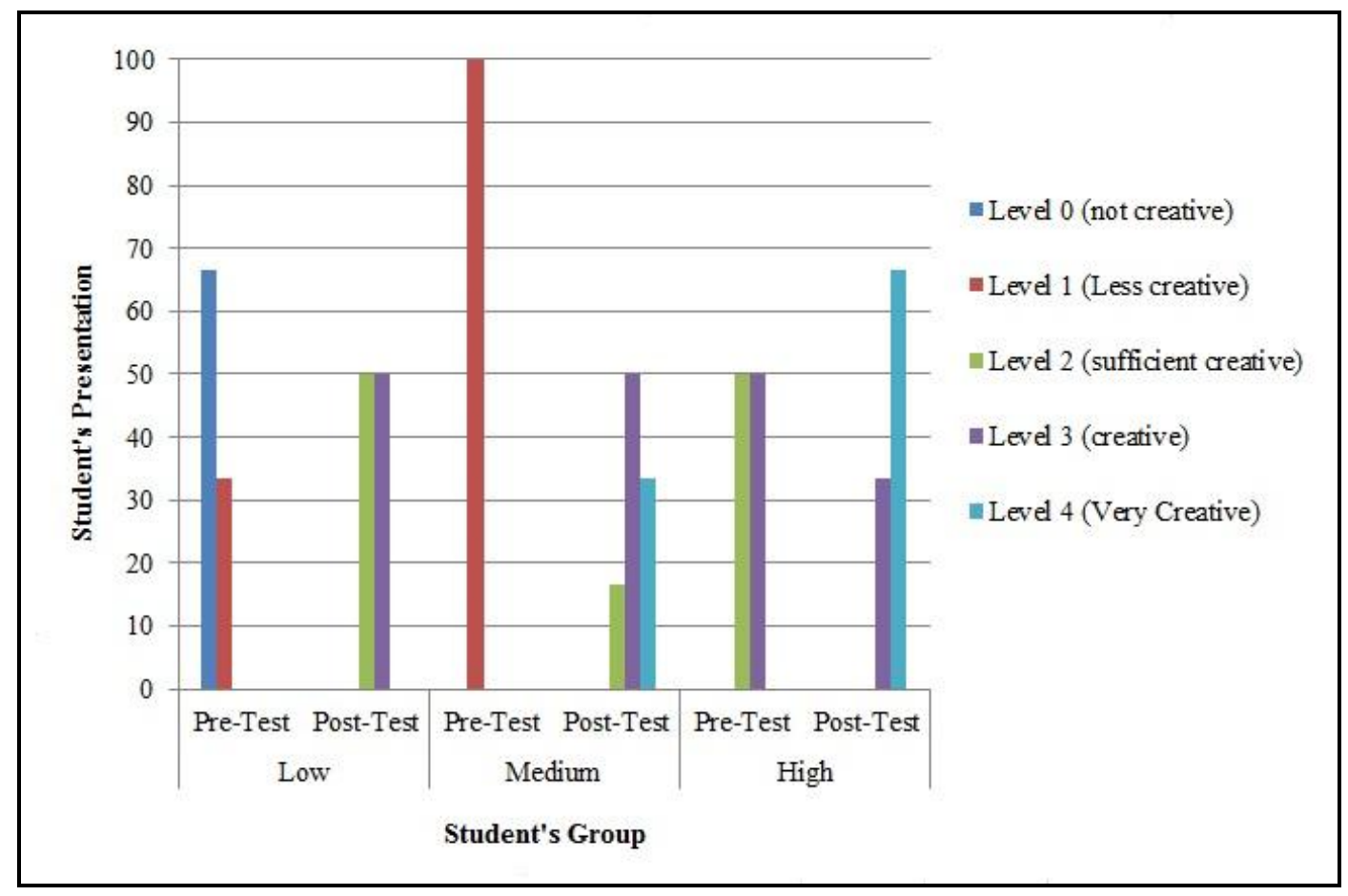

Figure 7. The Data of Achievement Indicators of Students' Creative Thinking Skills

Based on Figure 7, shows that the percentage of pre-test and post-test results changed significantly for all levels. The vast majority of low-level pupils are at levels 0 through 2 or 3 . The majority of students go from level 1 to level 3, resulting in an increase of middle-level pupils. Another boost in high-level pupils is produced by moving the majority of students from level 2 or 3 to level 4 . The outcomes of the rise in all indicators Students' creative thinking abilities are inextricably linked to the direction of the research-based learning process. These findings are congruent with the findings of Bani 's research, which suggests that the guided discovery technique may improve students' mathematical reasoning (Faizasari \& Permana, 2020; Fauzi \& Respati, 2021; Isnarto, 2020; Noer, Gunowibowo, \& Triana, 2020; T. D. Rahmawati, Sulisworo, \& Prasetyo, 2020). This form of instruction not only forces pupils to be more active, but it also directs them. According to Dunlosky, Rawson, Marsh, Nathan, \& Willingham (2013), if students are actively involved in finding concepts, they will comprehend them better, their memory will remain longer, and they will be able to employ them in various settings.

\section{CONCLUSION}

Based on the study data, the findings of the analysis, and the discussion that have been provided, it is possible to infer that: (1) the creative thinking abilities of students at mathematics education in the topic of combinatorics were in the high category. This was obtained based on the analysis of student characteristics toward mathematical creative thinking skills in each predicate increasing

Alifmatika: Jurnal Pendidikan dan Pembelajaran Matematika, December 2021, Vol. 3, No. 2 
significantly; (2) The elements that impact the student's capacity to think creatively in the course of combinatorics, according to the analysis, include accuracy in extending current data to create a formula or function, through to the form of the existing parameters. The inclination of students to rely on memory, imitation, and incentive; (3) In measuring the metacognitive level students' would be better if it is always implied at any time because the level of metacognitive someone is always evolving with age and influenced routine exercises. One of the subjects that can develop the metacognitive skills of students' is a course of combinatorics. This way students' can develop metacognitive skills. When students' begin to develop metacognitive skills, the level of student thinking is not only always up to the third level only, but can rise to a higher level, namely level 4; (4) For students' should be able to apply the learning process meaningful in receiving material or conceptual the concept is given. They should be more active in every learning and not only focused on the concepts taught by lecturers, so that will increase their creative thinking skills; and (5) The educators or researchers should carry out continuous research to students', especially related to the material of combinatorics. It meant that the creative thinking skills of mathematics students' can be trained and developed. In addition, educators or researchers should be able to apply meaningful learning in the classroom that can activate and maximize the potential of students' driven by a variety of learning approaches.

\section{ACKNOWLEDGEMENTS}

We gratefully acknowledge the support from Tarbiyah Faculty of Ibrahimy University, Situbondo, Indonesia, 2021.

\section{REFERENCES}

Abidin, Z., \& Tohir, M. (2019). Keterampilan Berpikir Tingkat Tinggi dalam Memecahkan Deret Aritmatika Dua Dimensi Berdasarkan Taksonomi Bloom. Alifmatika: Jurnal Pendidikan Dan Pembelajaran Matematika, 1(1), 44-60. https://doi.org/10.35316/alifmatika.2019.v1i1.44-60

Barak, M. (2010). Motivating self-regulated learning in technology education. International Journal of Technology and Design Education, 20(4), 381-401.

Binkley, M., Erstad, O., Herman, J., Raizen, S., Ripley, M., Miller-Ricci, M., \& Rumble, M. (2012). Defining twenty-first century skills. In Assessment and teaching of 21st century skills (pp. 17-66). Springer.

Dunlosky, J., Rawson, K. A., Marsh, E. J., Nathan, M. J., \& Willingham, D. T. (2013). Improving students' learning with effective learning techniques: Promising directions from cognitive and educational psychology. Psychological Science in the Public Interest, 14(1), 4-58.

Faizasari, A., \& Permana, D. (2020). Senior high school mathematics learning device development based on guided discovery to improve students' reasoning ability (preliminary research). Journal of Physics: Conference Series, 1481(1), 12129. IOP Publishing.

Alifmatika: Jurnal Pendidikan dan Pembelajaran Matematika, December 2021, Vol. 3, No. 2 
Fauzi, A., \& Respati, D. K. (2021). Development of Students' Critical Thinking Skills Through Guided Discovery Learning (GDL) and Problem-Based Learning Models (PBL) in Accountancy Education. Eurasian Journal of Educational Research, (95), 210-226.

Gartmann, S., \& Freiberg, M. (1995). Metacognition and Mathematical Problem Solving: Helping Students to Ask the Right Questions. Metacognition and Mathematical Problem Solving: Helping Students to Ask the Right Questions, $6(1)$.

Hargrove, R. A. (2013). Assessing the long-term impact of a metacognitive approach to creative skill development. International Journal of Technology and Design Education, 23(3), 489-517.

Isnarto, I. (2020). Mathematical communication of 7th-grade students viewed from the attitude of curiosity in Guided Discovery Learning assisted by educational props. Unnes Journal of Mathematics Education, 9(1), 20-27.

Kholid M. N.; Lestari, N. P. (2019). Metakognitif Siswa dalam Menyelesaikan Soal Matematika Berbasis PISA pada Konten Change and Relationship. Universitas Muhamadiyah Surakarta, (1), 121.

Munandar, U. (2012). Pengembangan Kreativitas Anak Berbakat. Jakarta: Rineka Cipta.

Munawwarah, M., Laili, N., \& Tohir, M. (2020). Keterampilan Berpikir Kritis Mahasiswa dalam Memecahkan Masalah Matematika Berdasarkan Keterampilan Abad 21. Alifmatika: Jurnal Pendidikan Dan Pembelajaran Matematika, 2(1), 37-58. https://doi.org/10.35316/alifmatika.2020.v2i1.3758

Muttaqin, H., Susanto, S., Hobri, H., \& Tohir, M. (2021). Students' creative thinking skills in solving mathematics higher order thinking skills (HOTS) problems based on online trading arithmetic. Journal of Physics: Conference Series, 1832(1), 12036. https://doi.org/10.1088/1742-6596/1832/1/012036

Noer, S. H., Gunowibowo, P., \& Triana, M. (2020). Development of guided discovery learning to improve students reflective thinking ability and self learning. Journal of Physics: Conference Series, 1581(1), 12041. IOP Publishing.

Preiss, D. D., Cosmelli, D., Grau, V., \& Ortiz, D. (2016). Examining the influence of mind wandering and metacognition on creativity in university and vocational students. Learning and Individual Differences, 51(1), 417-426.

Rahmawati, N. T. (2016). Kemampuan Berpikir Kreatif Matematik Siswa pada Pembelajaran SSCS dengan Tinjauan Metakognisi. PRISMA, Prosiding Seminar Nasional Matematika, (2), 150-160.

Rahmawati, T. D., Sulisworo, D., \& Prasetyo, E. (2020). Enhancing Students' Motivation and Problem Solving Skills in Mathematics Using Guided Discovery Learning. Universal Journal of Educational Research, 8(12), 6783-6789.

Romli, M. (2012). Strategi Membangun Metakognisi Siswa SMS dalam Pemecahan Masalah Matematika. Aksioma: Jurnal Matematika Dan Pendidikan Matematika 
UPGRIS Semarang, 1(2).

Sari, A. P., Ikhsan, M., \& Saminan, S. (2017). Creative Thinking Process of Students in Solving Mathematical Problems Based on Wallas Model. Beta Tadris Mathematics Journal, 10(1), 18-32.

Sitorus, J. (2016). Students' creative thinking process stages: Implementation of realistic mathematics education. Thinking Skills and Creativity, 22(1), 111120.

Sowden, P. T., Pringle, A., \& Gabora, L. (2015). The shifting sands of creative thinking: Connections to dual-process theory. Thinking \& Reasoning, 21(1), 40-60.

Suntusia, S., Dafik, D., \& Hobri, H. (2021). The Level of Critical Thinking Skill on Solving Two-Dimensional Arithmetics Problems Through Research-Based Learning. Alifmatika: Jurnal Pendidikan Dan Pembelajaran Matematika, 3(1), 55-69.

Tohir, M., Atikurrahman, M., Maswar, M., Daulay, L. A., Minhaji, M., Albadri, A., \& Sardjono, W. (2021). Building a caring community in problem based learning to improve students' mathematical connection capabilities. Journal of Physics: Conference Series, 1839(1), 12008. https://doi.org/10.1088/1742$6596 / 1839 / 1 / 012008$

Tohir, M. (2017). Pengembangan Bahan Ajar Olimpiade Matematika Berdasarkan Model Pemecahan Masalah untuk Meningkatkan Kemampuan Penalaran Matematis Siswa. In Tesis. Magister Pendidikan Matematika Universitas Jember. https://doi.org/10.13140/RG.2.2.31121.79200

Tohir, M. (2019). Keterampilan Berpikir Kreatif Siswa dalam Menyelesaikan Soal Olimpiade Matematika Berdasarkan Level Metakognisi. Alifmatika: Jurnal Pendidikan Dan Pembelajaran Matematika, 1(1), 1-14. https://doi.org/10.35316/alifmatika.2019.v1i1.1-14

Tohir, M., Abidin, Z., Dafik, D., \& Hobri, H. (2018). Students Creative Thinking Skills in Solving Two Dimensional Arithmetic Series Through Research-Based Learning. Journal of Physics: Conference Series, 1008(1), 012072. https://doi.org/10.1088/1742-6596/1008/1/012072

Tohir, M., Maswar, M., Atikurrahman, M., Saiful, S., \& Rizki Pradita, D. A. (2020). Prospective teachers' expectations of students' mathematical thinking processes in solving problems. European Journal of Educational Research, 9(4), 1735-1748. https://doi.org/10.12973/EU-JER.9.4.1735

Tohir, M., Susanto, S., Hobri, H., Suharto, S., \& Dafik, D. (2018). Students' Creative Thinking Skills in Solving Mathematics Olympiad Problems Based on ProblemSolving Polya and Krulik-Rudnick Model. Advanced Science Letters, 24(11), 8361-8364. https://doi.org/10.1166/asl.2018.12563 